\title{
Penegakan Hukum Pidana terhadap Anak yang Terjerat Perkara Pidana melalui Diversi (Studi Di Polrestabes Medan)
}

\section{Criminal Law Enforcement Against Children Involved in Criminal Cases Through Diversity (Study at Medan District Police)}

\author{
Akala Fikta Jaya*, Triono Eddy \& Alpi Sahari \\ Program Magister Ilmu Hukum, Universitas Muhammadiyah Sumatera Utara, Indonesia \\ Diterima: Juni 2020; Disetujui: Agustus 2020; Dipublish: Agustus 2020 \\ Correspondingemail:akalafiktajaya@gmail.com
}

\begin{abstract}
Abstrak
Pada masa lalu pemidanaan terhadap anak sama dengan pemidanaan terhadap orang dewasa. Hal itu menyebabkan kondisi psikologis anak mulai dari penyidikan, penyelidikan dan pengadilan menjadi terganggu karena kerap diintimidasi oleh aparat hukum. Berdasarkan kondisi tersebut maka lahirlah Undang-undang No 11 Tahun 2012 tentang Sistem Peradilan Pidana Anak. Berdasarkan hasil penelitian bahwa konsepsi penjatuhan pidana terhadap anak yang berkonflik dengan hukum di Indonesia adalah berbeda dengan penjatuhan pidana kepada orang dewasa. Anak-anak diberikan pemidanaan yang seringan mungkindan setengah dari penjatuhan pidana pelaku tindak pidana dewasa. Bahwa pertanggungjawaban pidana terhadap anak yang terjerat perkara pidana menurut Undang-Undang Sistem Peradilan Pidana Anak adalah tetap dilakukan namun berbeda sanksi hukumnya dengan orang dewasa. Penjatuhan pidana terhadap anak adalah upaya yang bersifat ultimumremedium, artinya penjatuhan pidana terhadap anak merupakan upaya hukum yang terakhir setelah tidak ada lagi upaya hukum lain yang menguntungkan bagi anak. Bahwa konsep penegakan hukum pidana terhadap anak yang terjerat perkara pidana melalui diversi adalah dalam faktanya memang belum semua menerapkannya. Beberapa kasus pidana yang melibatkan anak sebagai pelakunya, dalam proses pengadilan masih saja ada hakim yang menjatuhkan pidana penjara kepada anak yang berhadapan dengan hukum.
\end{abstract}

Kata Kunci: Hukum, Anak, Pidana, Diversi.

\begin{abstract}
In the past, the punishment of children was the same as the punishment of adults. This causes the psychological condition of children ranging from investigation, investigation and trial to be disturbed because it is often intimidated by law enforcement agencies. Under these conditions, Law No. 11 of 2012 concerning the Juvenile Justice System was born. One of the reforms in the Child Criminal Justice System Law requires the settlement of a child criminal case by diversion. Based on the results of research that the conception of criminal offenses against children in conflict with the law in Indonesia is different from criminal convictions to adults. Children are given the lightest possible punishment and half of the criminal convictions of adult criminal offenses. That criminal liability for children who are ensnared in a criminal case according to the Law on the Criminal Justice System for Children is still carried out but with different legal sanctions from adults. Criminal imprisonment against children is an ultimumremedium effort, meaning that criminal imprisonment against children is the last legal remedy after there are no other legal remedies that benefit the child. That the concept of enforcement of criminal law against children caught in criminal cases through diversion is in fact not all have applied it. Some criminal cases involving children as the culprit, in court proceedings there are still judges who impose prison sentences on children who are dealing with the law.
\end{abstract}

Keywords: Law, Children, Criminal, Diversified.

How to Cite: Jaya, A.F., Eddy, T. \& Sahari, A. (2020). Penegakan Hukum Pidana Terhadap Anak Yang Terjerat Perkara Pidana Melalui Diversi (Studi Di Polrestabes Medan). Journal of Education, Humaniora and Social Sciences (JEHSS), 3(1):1-10. 


\section{PENDAHULUAN}

Tindak pidana yang terjadi saat ini di masyarakat bukan saja pelakunya orang dewasa, bahkan terjadi kecenderungan pelakunya adalah masih tergolong usia anak-anak. Oleh karena itu, berbagai upaya pencegahan dan penanggulangan kenakalan anak perlu segera dilakukan. (Nandang, 2010) .Setiap tahun, lebih dari 2.000 anak Indonesia diajukan ke pengadilan atas kejahatan ringan, seperti pencurian, miras. Pada proses hukum yang mereka jalani, sangat jarang yang didampingi oleh pengacara, pekerja sosial maupun pemerintah (dalam hal ini dinas sosial). Sehingga jumlah anak konflik hukum yang menjadi anak didik pemasyarakatan semakin hari semakin bertambah dan kapasitas lembaga pemasyaraatan (LP) semakin tidak mencukupi sehingga tidak jarang pula yang ditempatnya dalam LP orang dewasa. Kondisi ini sangat memprihatinkan karena anak harus berhadapan dengan sistem peradilan dan mereka ditempatkan di tempat penahanan dan pemenjaraan bersama orang dewasa, tentu kondisi ini memposisikan anak subordinat dan rawan akan tindak kekerasan dari orang dewasa. (Wiwik, 2014)

Penjelasan UU. No.23 Tahun 2002 tentang Perlindungan Anak menyatakan bahwa kejahatan (Crime) yang dilakukan oleh orang dewasa, tidak dapat disamakan begitu saja dengan perbuatan anak atau remaja (Juvenile Delinquency) yang biasa dilakukan oleh anak, sebab harus dibedakan sifat dan bentuk perbuatan seorang anak dengan perbuatan orang dewasa. Perlindungan terhadap anak dalam kaitannya anak yang bermasalah dengan hukum, sebagai bagian utama peningkatan kualitas mutu hidup manusia. Sesuai UU No. 23 Tahun 2002 yaitu segala kegiatan untuk menjamin dan melindungi anak dan hak-haknya agar dapat hidup tumbuh, berkembang, dan berpartisipasi, secara optimal sesuai dengan harkat dan martabat kemanusiaan, serta mendapat perlindungan dari kekerasan dan diskriminasi.

Berbagai faktor yang mempengaruhi penyimpangan tingkah laku maupun perbuatan melanggar hukum yang dilakukan anak, antara lain adanya dampak negatif perkembangan, pembangunan yang cepat, globalisasi, kemajuan ilmu pengetahuan, teknologi, komunikasi, serta perubahan gaya hidup orang tua yang mempengaruhi nilai dan perilaku anak.

Menurut Arif Gosita melindungi anak pada hakikatnya adalah melindungi keluarga, masyarakat, nusa, dan bangsa. (Arief, 1989) Kemungkinan terjadinya penyalahgunaan kekuasaan dan kekuatan pada waktu pelaksanaan pidana, dapat menimbulkan viktimisasi mental, fisik, dan sosial pada anak pidana. Tidak adanya peraturan perundang-undangan yang dapat menjadi dasar pemidanaan yang tepat, juga dapat menyebabkan adanya viktimisasi struktural, yang dapat menimbulkan penderitaan mental, fisik, dan sosial pada para anak pidana.

Berdasarkan Undang-Undang Nomor 11 Tahun 2012, penyelesaian perkara anak lebih mengedepankan proses di luar peradilan dengan melibatkan pelaku, korban, keluarga pelaku/korban, dan pihak lain yang terkait untuk bersama-sama mencari penyelesaian yang adil dengan menekankan pemulihan kembali pada keadaan semula, dan bukan pembalasan untuk mencari keadilan restoratif sebagaimana diatur dalam Pasal 1 ayat (6) Undang-Undang Nomor 11 Tahun 2012 tentang Sistem Peradilan Anak.

Hal yang perlu diperhatikan bahwa pada setiap tingkatan penanganannya (kepolisian, kejaksaan dan pengadilan), maka pendekatan kesejahteraan harus dapat dijadikan sebagai dasar filosofi penanganan terhadap pelanggaran hukum usia anak. Pada prinsipnya pendekatan ini didasari 2 (dua) faktor, yaitu:

1. Anak-anak dianggap belum mengerti benar kesalahan yang telah diperbuat, sehingga sudah sepantasnya diberikan pengurangan hukuman, serta pembedaan pemberian hukuman bagi anak-anak dengan orang dewasa.

2. Bila dibandingkan dengan orang dewasa, anak-anak diyakini lebih mudah dibina dan disadarkan. (Kristina, 2016)

\section{METODE PENELITIAN}

Penelitian ini adalah penelitian hukum normatif, yang bersifat deskriptif analisis, dengan pendekatan perundang-undangan (statute approach), pendekatan konseptual (conceptual 
approach), dan pendekatan kasus (case approach), sedangkan sumber data yang dipakai adalah sumber data sekunder, teknik pengumpulan data melalui studi kepustakaan, serta dianalisis dengan analisis kualitatif. Tindak Pidana adalah perbuatan melakukan atau tidak melakukan sesuatu yang memiliki unsur kesalahan sebagai perbuatan yang dilarang dan diancam dengan pidana, dimana penjatuhan pidana pada pelaku adalah demi tertib hukum dan terjaminya kepentingan umum (Lamintang, 1996)

Berdasarkan Dalam Pasal 1 ayat (2) Undang-Undang Sistem Peradilan Pidana Anak mengatur, bahwa: anak yang melanggar hukum adalah anak yang bermasalah dengan pelanggaran hukum, anak sebagai korban pelaku pidana dan anak yang jadi saksi perbuatan pidana. Pasal 1 ayat (3) Undang-Undang Sistem Peradilan Pidana Anak, ditentukan bahwa: Anak yang bermasalah dengan pelanggaran hukum yang selanjutnya disebutkan bahwa Anak adalah manusia yang sudah mencapai umur 12 tahun, tetapi belum mencapai usia 18 tahun yang masih diduga-duga melakukan perbuatan pidana. Selanjutnya dalam Pasal 1 ayat (4) Undang-Undang Sistem Peradilan Pidana Anak menyatakan anak yang menjadi korban perbuatan pidana yang disebut Anak sebagai Korban adalah anak yang masih dibawah usia 18 tahun penderita fisik, mental, dan kerugian materil yang disebabkan oleh perbuatan pidana yang dilakukan (Surbakti, dkk., 2019; Ritonga, dkk., 2019; Ginting, dkk., 2018; Hia, dkk., 2019).

Diversi adalah suatu pengalihan penyelesaian perkara Anak dari proses peradilan pidana ke proses di luar peradilan pidana (Pasal 1 angka 7 UU. Sistim Peradilan Anak ). Dengan demikian konsep Diversi adalah pengalihan penyelesaian kasus-kasus anak yang diduga melakukan tindak pidana tertentu dari proses pidana formal ke penyelesaian damai antara tersangka/ terdakwa/pelaku tindak pidana dengan korban yang difasilittasi oleh keluarga dan/atau masyarakat, Pembimbing Kemasyarakatan Anak, Polisi, Jaksa atau Hakim. (Komariah, 2016)

\section{HASIL DAN PEMBAHASAN}

Konsepsi Penjatuhan Pidana terhadap Anak yang Berhadapan dengan Hukum di Indonesia

Saat ini banyak sekali pidana yang diberikan pada anak yang masih dibawah umur akibat kenakalan remaja yang dilakukan membawa anak yang biasa disebut sebagai anak nakal terjerat dalam permasalahan hukum dan melalui proses peradilan anak, sehingga diberikan hukuman (pidana) terhadapnya. Ketentuan kejahatan anak atau disebut delikuensi anak diartikan sebagai bentuk kejahatan yang dilakukan anak dalam title-titel khusus dari bagian KUHP dan atau tata peraturan perundang-undangan, (Lamintang, 1996)

Saat ini telah ada undang-undang baru yang telah disahkan dan akan diberlakukan pada tahun 2014 tentang Sistem Peradilan Pidana Anak Nomor 11 Tahun 2012 yang juga menerangkan:

Pasal 81 Ayat (1) bahwa "Pidana penjara yang dapat dijatuhkan kepada anak paling lama $1 / 2$ (satu perdua) dari maksimum ancaman pidana penjara bagi orang dewasa". Pasal 81 Ayat (6) bahwa "Jika tindak pidana yang dilakukan Anak merupakan tindak pidana yang diancam dengan pidana mati atau pidana penjara seumur hidup, pidana yang dijatuhkan adalah pidana penjara paling lama 10 (sepuluh) tahun".

Pada sistem peradilan pidana anak dalam undang undang yang baru terdapat istilah keadilan restoratif hal ini tertuang dalam Pasal 1 Angka 6 UU Nomor 11 Tahun 2012 tentang Sistem Peradilan Pidana Anak. Keadilan Restoratif adalah penyelesaian perkara tindak pidana dengan melibatkan pelaku, korban, keluarga pelaku/korban, dan pihak lain yang terkait untuk bersamasama mencari penyelesaian yang adil dengan menekankan pemulihan kembali pada keadaan semula, dan bukan pembalasan.

\section{Pertanggungjawaban Pidana Terhadap Anak Yang Terjerat Perkara Pidana Menurut Undang-Undang Sistem Peradilan Pidana Anak}

Filosofi sistem peradilan pidana anak yaitu mengutamakan perlindungan dan rehabilitasi terhadap pelaku anak sebagai orang yang masih mempunyai sejumlah keterbatasan dibandingkan dengan orang dewasa. Anak memerlukan perlindungan dari negara dan masyarakat dalam jangka waktu ke depan yang masih panjang. Terhadap anak yang terlanjur menjadi pelaku tindak pidana 
diperlukan strategi sistem peradilan pidana yaitu mengupayakan seminimal mungkin intervensi sistem peradilan pidana (Zai, dkk, 2011; Saragih, dkk, 2019; Lubis, dkk., 2019; Akhbar, dkk., 2019).

Perlindungan terhadap anak melalui pemberlakuan asas ultimum remedium telah dilakukan tidak hanya di dalam perangkat aturan internasional tetapi juga di dalam perangkat hukum nasional dan di dalam putusan pengadilan yang mengadili tentang anak, (Beby, 2007).

Penjatuhan pidana kepada anak harusnya merupakan upaya terakhir yang dapat dilakukan, sehingga hukum pidana tersebut bersifat ultimum remedium, yaitu upaya terakhir guna memperbaiki tingkah laku manusia terutama penjahat serta memberikan tekanan psikologis agar orang lain tidak melakukan kejahatan. (Zainal, 2007).

Ultimum remedium tidak hanya berarti berhemat dalam menegakkan hukum pidana. Jadi, hukum pidana bersifat ultimum remedium, bukan hanya dalam tataran formulasi ( yaitu ketika memutuskan untuk menetapkan suatu perbuatan sebagai tindak pidana), tetapi juga dalam tataran aplikasi (yaitu ketika menerapkan hukum pidana terhadap peristiwa konkrit).

Asas ultimum remedium bukanlah asas konstitusional, namun lebih pada etika legislatif, mulai saat kriminalisasi atau menjadikan suatu perbuatan yang semula bukan tindak pidana menjadi tindak pidana. Doktrin ini harus dipahami dalam kerangka asas-asas yang berkaitan dengan nilai-nilai kebutuhan, efisiensi, keterbatasan, asas kemanfaatan, pertimbangan analisa biaya dan hasil serta asas kemanusiaan, baik yang berkaitan dengan kepentingan pelaku maupun kepentingan korban tindak pidana.

Berdasarkan keterangan informan yang ada di Polrestabes Medan ditemukan bahwa beberapa kasus yang melibatkan anak sebagai pelakunya memang ada yang dikenakan tindakan tegas, misalnya pelaku begal yang dalam beberapa tahun ini meresahkan warga kota Medan. Terhadap pelaku begal ini, pihak Unit PPA Polrestabes Medan, melakukan penyidikan yang agak keras meskipun tidak kasar, untuk mengungkap kasus-kasus begal. Kasus-kasus begal yang terjadi di kota Medan, sebagian memang dilakukan oleh kalangan pelajar, yang notabenenya masih dibawah umur. Tindakan agak keras dalam proses penyidikan kasus begal di Unit PPA Polrestabes Kota Medan, agar para pelaku yang biasanya berkelompok, dapat diketahui para pelaku lainnya.

Dalam kasus begal ini, anak yang berhadapan dengan hukum, biasanya tidak diambil kebijakan untuk diskresi, karena pertimbangan penyidikan dan penyelidikan yang agak intensif, maka tidak diberikan diskresi sebab dikhawatirkan pelaku akan melarikan diri serta menghilangkan barang bukti.

Keterangan informan dari Unit PPA Polrestabes Medan menyatakan bahwa dalam beberapa kasus pidana yang melibatkan anak di bawah umur sebagai pelakunya, misalnya kasus perkelahian, tetap diupayakan untuk dilakukan perdamaian antara kedua belah pihak yang berselisih tersebut. Hal ini dilakukan untuk tercapainya salah satu tujuan pemidanaan, yaitu deterrence yang artinya pencegahan. Teori deterrence memandang bahwa pemidanaan bukan sebagai pembalasan atas kesalahan pelaku, akan tetapi merupakan sarana untuk mencapai tujuan yang bermanfaat untuk melindungi masyarakat menuju kesejahteraan masyarakat.

\section{Konsep Penegakan Hukum Pidana Terhadap Anak Yang Terjerat Perkara Pidana Melalui Diversi}

Diversi merupakan proses diskresi yang dilakukan komponen sistem peradilan pidana (Kepolisian, Kejaksaan, Pihak Pengadilan) yang ditujukan kepada anak yang berkonflik dengan hukum. Diversi merupakan kebijakan yang dilakukan untuk menghindarkan pelaku dari sistem peradilan pidana formal. Diversi dilakukan untuk memberikan perlindungan dan rehabilitasi (protection and rehabilitation) kepada pelaku sebagai upaya untuk mencegah anak menjadi pelaku kriminal dewasa.

Terdapat beberapa manfaat pelaksanaan program diversi bagi anak sebagai pelaku, yaitu:

1. Membantu anak belajar dari kesalahannya.

2. Memperbaiki luka karena kejadian tersebut, kepada korban dan masyarakat.

3. Kerjasama dengan para orang tua, pengasuh dan diberi nasihat.

4. Melengkapi dan membangkitkan anak-anak untuk membuat keputusan bertanggung jawab. 
5. Memberikan rasa tanggung jawab atas perbuatannya dan memberikan pelajaran tentang kesempatan untuk mengamati akibat-akibat dan efek dari kejadian tesebut.

6. Mengurangi beban pada peradilan dan lemabaga pemasyarakatan.

Untuk melihat sejauh mana penerapan diversi terhadap anak yang berhadapan dengan hukum, maka berikut ini ada beberapa kasus yang melibatkan anak sebagai tersangkanya.

Kasus Perkara Nomor 20/Pid.Sus-Anak/2014/PN.Mks.Kasus ini melibatkan Terdakwa Sultan Hasanuddin (17 tahun), bersama dengan Sikri dan Dedi ini bermula pada hari Kamis tanggal 14 Agustus 2014 sekitar pukul 21.00 WITA, saat itu korban yang bernama Andi Najamuddin berboncengan dengan temannya yang bernama Ayu melewati Jl. Balang baru dimana pada saat yang sama terdakwa bersama dua temannya yaitu Sikri dan Dedi sedang jongkok-jongkok di pinggir kanal. Ketika korban melewati terdakwa dan rekannya, korban mengatakan permisi sambil menundukkan kepalanya, kemudian rekan terdakwa bernama Sikri memanggil korban untuk singgah namun korban tidak mau singgah, sehingga terdakwa dan dua rekannya mengejar korban. Setelah terdakwa dan rekannya berhasil mengejar korban, rekan terdakwa yang bernama Sikri memukul korban menggunakan tanggannya secara berulang kali yang mengenai pelipis kanan, dahi kiri, jidat, dagu dan punggung korban. Kemudian terdakwa memukul korban menggunakan tangan kanannya ke arah muka korban lalu menendang dada korban. Rekannya yang bernama Dedi juga ikut memukul muka dan menendang korban. Alasan mereka melakukanpenganiayaan terhadap korban dikarenakan tersangka sakit hati, sebelumnya ada teman tersangka yang bernama Didin dibusur oleh anak dangko yang tidak diketahui namanya. Akibat perbuatan penganiayaan bersama teman-temannya, menyebabkan korban Andi Najamuddin Alias Andi mengalami luka bengkak dan memar sebagaimana surat Visum et Repertum tanggal 26 Agustus 2014.

Dalam proses pemeriksaan yang dilakukan oleh penyelidik diketahui bahwa telah terjadi tindakan penganiayaan. Hal ini didasari pada laporan korban yang sesaat setelah kejadian tindak pidana penganiayaan yang dilakukan oleh terdakwa. Berdasarkan laporan tersebut polisi kemudian menangkap tersangka Sultan Hasanuddin. Dalam proses penyidikan, pihak kepolisian telah melakukan upaya mediasi untuk mempertemukan antara korban, pelaku dan keluargannya.

Dalam proses penyidikan, pihak kepolisian yang diwakili oleh penyidik selalu melakukan upaya mediasi dalam menangani perkara tindak pidana yang dilakukan oleh anak. Proses mediasi yang dalam hal ini menjadi konsep diversi dilakukan dengan mempertemukan pihak korban dan keluarganya dengan pihak tersangka dan juga pihak-pihak yang secara tidak langsung berkaitan dengan tindak pidana yang terjadi.

Dalam proses tersebut penyidik menjelaskan terlebih dahulu kepada keluarga korban tentang duduk perkara yang sedang terjadi dengan melibatkan tersangka dan korban. Selanjutnya penyidik mempersilahkan kepada tersangka untuk mengutarakan keinginannya untuk berdamai dengan korban. Setelah itu, korban ataupun yang mewakilinya untuk berbicara tentang apa yang dinginkan oleh pihak korban.

Proses diversi selanjutnya dilakukan di kejaksaan setelah pelimpahan berkas perkara dari penyidik kepolisian kepada jaksa penuntut umum di kejaksaan. Kasus-kasus tindak pidana yang melibatkan anak selalu diupayakan diversi. Akan tetapi, sebagai pihak yang ikut melakukan upaya diversi, penuntut umum belum bisa melakukan diversi di kejaksaan. Hal ini dikarenakan karena peraturan pelaksana dari Jaksa Agung sebagai peraturan turunan dari undang-undang yang mengatur diversi belum dikeluarkan. Keadaan ini menjadikan penuntut umum tidak mampu melakukan upaya diversi sendiri meskipun ada undang-undang yang mengaturnya. Upaya diversi yang selama ini selalu dilakukan bersama hakim sebagai fasilitator diversi di Pengadilan Negeri.

Dalam proses persidangan, titik urgensi terletak pada peran hakim dan penasihat hukum dari Pos Bantuan Hukum (Posbakum) Pengadilan Negeri Makassar sebagai fasilitator pengupayaan diversi dalam perkara pidana yang melibatkan anak, sehingga, Mahkamah Agung melihat sebuah tujuan yang sangat bermanfaat dari proses diversi ini dengan mengeluarkan Peraturan Mahkamah Agung Republik Indonesia (PERMA) Nomor 4 Tahun 2014 Tentang Pedoman Pelaksanaan Diversi Dalam Sistem Peradilan Pidana Anak. 
Berdasarkan amanat Undang-Undang untuk melakukan upaya diversi pada setiap tingkat pemeriksaan, maka berdasarkan PERMA Nomor 4 Tahun 2014 sebelum proses persidangan dimulai, hakim wajib melakukan upaya diversi untuk mendamaikan terdakwa dan korban. Pada kasus ini, akhirnya tercapai kesepakatan antara terdakwa (Sultan) dan korban (Andi Najamuddin).

Adapun kesepakatan yang terjalin antara terdakwa dan korban, yaitu :

1. Terdakwa berjanji tidak akan mengulangi kembali perbuatan yang dilakukannya; dan

2. Orang tua terdakwa dan terdakwa mengganti seluruh biaya pengobatan korban.

Dengan adanya kesepakatan tersebut, maka hakim yang memeriksa perkara tersebut sekaligus menjadi fasilitator diversi mengeluarkan penetapan yang isinya sebagai berikut:

1. Menyatakan penghentian pemeriksaan perkara Nomor: 20/Pid.Sus-Anak/2014/PN.Mks. atas nama Terdakwa Sultan Hasanuddin alias Sultan;

2. Membebanan biaya perkara kepada negara.

Undang-Undang No. 23 Tahun 2002 di dalam Pasal 59 jo. Pasal 64 ayat 1 dan ayat 2. Dalam pasal tersebut di atas dijelaskan bahwa pemidanaan terhadap anak bukanlah semata-mata penghukuman tetapi rehabilitasi dalam rangka pendidikan dan pencegahan. Dengan demikian diberikannya hukuman kepada anak bukanlah sebagai pemberi rasa sakit namun sebagai pembinaan sehingga dengan pembinaan itu sebagai pemberi rasa sakit namun sebagai pembinaan sehingga dengan pembinaan diharapkan anak dapat menyadari perbuatannya dan dapat kembali ke tengah-tengah masyarakat untuk melanjutkan masa depannya.

Dengan adanya Undang-Undang Nomor 11 Tahun 2012 Tentang Sistem Peradilan Pidana Pidana Anak (UU-SPPA) memberikan landasan hukum secara legitimate bagi setiap instansi tersebut untuk melakukan upaya diversi. Upaya diversi yang dilakukan secara kelembagaan dijalankan oleh aparat yang berada di instansi tersebut mulai dari penyidik, penuntut umum dan Hakim di Pengadilan.

Undang-Undang Tentang Sistem Peradilan Pidana Anak mengatur tentang pelaksanaan diversi pada tingkat penyidikan, penuntutan dan pemeriksaan perkara di Pengadilan Negeri. Dalam Undang-Undang tersebut juga mengatur bagaimana proses diversi dilakukan dan terhadap tindak pidana apa saja yang dapat diupayakan pelaksanaan diversi. Adapun hal lain yang diatur dalam UU-SPPA adalah bentuk kesepakatan yang terjadi jika diversi berhasil dilakukan.

Adanya Undang-Undang Tentang Sistem Peradilan Pidana Anak menjadi pedoman bagi setiap instansi dalam hal ini penyidik di kepolisian, penuntut umum di kejaksaan dan hakim di pengadilan dalam melakukan upaya diversi terhadap kasus tindak pidana yang dilakukan oleh anak. Hal ini menjadi acuan para aparat penegak hukum sehingga secara kelembagaan mereka telah siap untuk menerapkan upaya diversi dalam setiap tahapan sistem peradilan pidana. Kesiapan tersebut akan berdampak pada efektifnya proses mediasi sebagai konsep diversi untuk mewujudkan keadilan restoratif pada anak baik selaku pelaku tindak pidana maupun sebagai korban tindak pidana.

\section{SIMPULAN}

Konsepsi penjatuhan pidana terhadap anak yang berkonflik dengan hukum di Indonesia adalah berbeda dengan penjatuhan pidana kepada orang dewasa. Anak-anak diberikan pemidanaan yang seringan mungkin dan setengah dari penjatuhan pidana pelaku tindak pidana dewasa. Hal tersebut terdapat Pasal 81 Ayat (1) UU SPPA bahwa "Pidana penjara yang dapat dijatuhkan kepada anak paling lama 1/2 (satu perdua) dari maksimum ancaman pidana penjara bagi orang dewasa". Pasal 81 Ayat (6) bahwa "Jika tindak pidana yang dilakukan Anak merupakan tindak pidana yang diancam dengan pidana mati atau pidana penjara seumur hidup, pidana yang dijatuhkan adalah pidana penjara paling lama 10 (sepuluh) tahun".

Pertanggungjawaban pidana terhadap anak yang terjerat perkara pidana menurut UndangUndang Sistem Peradilan Pidana Anak adalah tetap dilakukan namun berbeda sanksi hukumnya dengan orang dewasa. Penjatuhan pidana terhadap anak adalah upaya yang bersifat ultimumremedium, artinya penjatuhan pidana terhadap anak merupakan upaya hukum yang terakhir setelah tidak ada lagi upaya hukum lain yang menguntungkan bagi anak, misalnya anak 
itu memang sudah sangat meresahkan keluarga dan masyarakat, berkali-kali telah melakukan tindak pidana dan pihak orang tua atau wali sudah tidak ada lagi yang sanggup untuk mendidik dan mengawasinya.

Konsep penegakan hukum pidana terhadap anak yang terjerat perkara pidana melalui diversi adalah dalam faktanya memang belum semua menerapkannya. Beberapa kasus pidana yang melibatkan anak sebagai pelakunya, dalam proses pengadilan masih saja ada hakim yang menjatuhkan pidana penjara kepada anak yang berhadapan dengan hukum.

\section{DAFTAR PUSTAKA}

Afifah, W. (2014) "Pertanggungjawaban Pidana Anak Konflik Hukum", dalam DIH, Jurnal Ilmu Hukum, Volume 10, Nomor 19, Pebruari 2014, hlm. 48

Akhbar, A.T.F, Maswandi \& Kartika, A. (2019). Perlindungan Hukum Bagi Anak Dalam Tindak Pidana Pencurian Dengan Kekerasan Yang Mengakibatkan Matinya Korban (Studi Putusan No. 37/Pid.SusAnak/2017/PN. Mdn). JUNCTO, 1(2) 2019: 183-192,

Farid, Z.A. (2007), Hukum Pidana I, Jakarta: Sinar Grafika, hlm. 13.

Fithri, B.S. (2017)."Asas Ultimum Remedium Terhadap Anak Yang Berkonflik Dengan Hukum Dalam Rangka Perlindungan Anak", dalam Jurnal Mercatoria, Volume 10, Nomor 1, Juni 2017, hlm. 75.

Ginting, H. \& Zul, M. (2018). Peranan Kepolisian dalam Penerapan Restorative Justice terhadap Pelaku Tindak Pidana Pengeroyokan yang Dilakukan oleh Anak dan Orang Dewasa, Jurnal Ilmiah Penegakan Hukum, 5 (2): 32-40.

Gosita, A. (1989), Masalah Perlindungan Anak, Jakarta: Akademika Pressindo, hlm. 1.

Hia, H., Mulyadi, M. \& Siregar, T. (2019). Perlindungan Hukum Terhadap Anak Korban Kekerasan: Studi Kasus Putusan Pengadilan Negeri Gunungsitoli. ARBITER: Jurnal Ilmiah Magister Hukum, 1(2): 117-125.

Komariah, T.D.C, (2017) “ Efektifitas Konsep Diversi Dalam Proses Peradilan Anak Pelaku Tindak Pidana Menurut UU No. 11 Tahun 2012 Tentang Sistem Peradilan Pidana Anak (Dalam Proses Peradilan Anak Pelaku Tindak Pidana Di Kabupaten Malang)", dalam Jurnal Legality, Volume 24, Nomor 2, September 2016-Februari 2017, hlm. 268.

Lamintang, (1996), Dasar-Dasar Hukum Pidana Indonesia, Bandung: PT. Citra Aditya Bakti, hlm. 16.

Lubis, M.S., Hidayani, S. \& Zul, M. (2019). Kajian Hukum Terhadap Anak Berhadapan Hukum Dalam Tindak Pidana Pencurian Menurut Undang-Undang No. 11 Tahun 2012 Tentang Pengadilan Anak (Studi Putusan No. 67/Pid.Sus-Anak/2017/PN.Mdn). JUNCTO, 1(1) 2019: 100-112,

Ritonga, M. S., Mulyadi, M. \& Mustamam (2019). Penerapan Restorative Justice Sebagai Model Perlindungan terhadap Anak (Studi Penanganan Perkara Anak Berhadapan dengan Hukum pada Wilayah Hukum Pengadilan Negeri Dumai Kelas IA). Journal of Education, Humaniora and Social Sciences (JEHSS). 2 (2): 318-334.

Sambas, N, (2010), Pembaharuan Sistem Pemidanaan Anak di Indonesia, Yogyakarta: Graha Ilmu, hlm. 103.

Saragih, D.H.P., Rizkan, Z. \& Harahap, D.A. (2019). Akibat Hukum Terhadap Anak Sebagai Pelaku Tindak Pidana Pencurian Yang Menyebabkan Kematian (Studi Putusan Nomor : 45/Pid.Sus-Anak.2018/PN. Lbp). JUNCTO, 1(1) 2019: 78-88,

Sianturi, K.A. (2016) “Perwujudan Keadilan Restoratif Dalam Sistem Peradilan Pidana Anak Melalui Diversi”, dalam De Lega Lata Jurnal Ilmu Hukum, Volume 1, Nomor 1, Januri-Juni 2016, Medan: Fakultas Hukum Universitas Muhammadiyah Sumatera Utara, hlm. 185.

Surbakti, F.M. \& Zulyadi, R. (2019). Penerapan Hukum terhadap Anak sebagai Pelaku Tindak Pidana Pencurian dengan Kekerasan. Journal of Education, Humaniora, and Social Sciences (JEHSS), 2 (1): 143-166.

Zai, A., Siregar, T., dan Dedy I., (2011), Perlindungan Hukum Terhadap Anak yang Berhadapan dengan Hukum dalam Sistem Peradilan Anak, (Studi pada Wilayah Hukum Polres Nias), Mercatoria, 4 (2): 86103 